\title{
PHYTOCHEMICAL SCREENING AND PURGATIVE ACTIVITY OF ETHANOLIC EXTRACTS OF VERNONIA AMYGDALINA DEL. LEAF \\ Wazis $\mathrm{CH}^{1}$, Timothy $\mathrm{SY}^{1 *}$, Zakama $\mathrm{SG}^{2}$, Balla $\mathrm{HJ}^{3}$, Maspalma $\mathrm{ID}^{1}$ \\ ${ }^{1}$ Department of Pharmacology and Toxicology, Faculty of Pharmacy, University of Maiduguri, Maiduguri, Nigeria \\ ${ }^{2}$ Department of Pharmaceutics and Pharmaceutical Microbiology, Faculty of Pharmacy, University of Maiduguri, Maiduguri, Nigeria \\ ${ }^{3}$ Department of Medical Laboratory Science, College of Medical Sciences, University of Maiduguri, Maiduguri, Nigeria
}

Received on: 09/10/12 Revised on: 22/11/12 Accepted on: 16/12/12

\author{
*Corresponding author \\ E-mail: satiye2002@gmail.com \\ DOI: 10.7897/2277-4343.04122 \\ Published by Moksha Publishing House. Website www.mokshaph.com \\ All rights reserved.
}

\section{ABSTRACT}

Vernonia amygdalina has diverse ethno-medical uses including constipation. The aim of this study was to determine the phytochemical component and purgative effect of ethanolic extract of Vernonia amygdalina leaf on rabbit jejunum. Leaves of Vernonia amygdalina were collected, dried, ground and extracted using $95 \%$ ethanol. Isolated tissue of rabbit jejunum was challenged with acetylcholine as standard and different strength of the extract at dose ranges of $10 \mathrm{mg}$ to $160 \mathrm{mg}$ in a $50 \mathrm{ml}$ capacity organ bath. The preliminary phytochemical analysis revealed the presence of alkaloids, tannins, phlabotannins, saponins, and anthraquinones. Alkaloids, tannins, and saponins appeared in high quantities, while steroids and flavonoids were absent. The extract at concentrations of $0.2,0.4,0.8,1.6$ and $3.2 \mathrm{mg} / \mathrm{ml}$ produce contractile responses of $3.0,7.0,10.2,15.3$ and $15.0 \mathrm{~mm}$ respectively which were dose depended. Atropine was able to block the contraction exerted by the extract. These suggest that the extract may be acting on the muscarinic receptors $\left(\mathrm{M}_{3}\right)$ which are present on the intestine. This study amply justifies the ethno medical claim that the leaves are used as purgatives.

Keywords: Vernonia amygdalina, Purgative, Ethanol

\section{INTRODUCTION}

The revival of interest in the use of African medicinal plants by many developing countries and World Health Organization has led to intensified efforts to explore the numerous plants with medicinal importance. Research has been geared toward finding scientific evidence for the claims of African herb by traditional healers ${ }^{1,2}$. For many years, natural plant materials have been seen as a valuable source of medicinal agents with proven potential for treating diseases with lesser side effects compared to the synthetic drug agent ${ }^{3}$. Vernonia amygdalina is one among many plants that have multiple medicinal values used in different parts of Africa. It is a shrub that grows under a wide range of ecological zones in Nigeria. The leaves are used for human consumption and washed before eating to get rid of the bitterness. It is also used instead of hops to make beer in Nigeria. It is also found in homes and villages as fence ${ }^{4}$. The plant has many medicinal uses which include antibacterial, antidiabetic, antihelmintic, antioxidants, antimalarial and analgesic activity ${ }^{5}$. In some part of Nigeria the fresh leaves has been used as an appetizer, abortificient and purgative enemas ${ }^{6}$. Many herbalist recommend aqueous extract for their patients as treatment for emesis, loss of appetite and dysentery. In Northern part of Nigeria, the plants have been used for various gastrointestinal problems ${ }^{5,6}$. As a result of its ethno-medical usage it becomes necessary to evaluate the purgative effect of the plant Vernonia amygdalina.

\section{MATERIALS AND METHODS \\ Plant Material}

The leaves of the plant Vernonia amygdalina was obtained from a cultivated source from Vunoklang, Girei Local Government Area of Adamawa State, Nigeria. The leaves were collected in November, 2011 and were identified by Professor Sanusi O. Sanusi of Department of Biological Science, University of Maiduguri at which the voucher specimen number was assigned (26590) and deposited in the herbarium.

\section{Extraction of Vernonia amygdalina leaf}

The leaves of the plant were collected, air-dried at room temperature for 14 days, homogenized using a wooden pestle and mortar, grounded and finally sieved to obtain a finely divided powder. Three hundred and fifty grammes $(350 \mathrm{~g})$ of the powder was soaked in 1 liter of ethanol and thoroughly shaken. This was allowed to stand for 24 hours with intermittent shaking. Filtration was done to remove the coarse particles and fine particles were removed using Whitman filter paper in Buchner funnel. The sample was concentrated using rotary evaporator at $50^{\circ} \mathrm{C}$ to recover the solvent. The weight of the ethanol extract was $15.1 \mathrm{~g}$, giving a percentage yield of $4.31 \%$.

Preparation of stock solutions of extract and standard One gram of the extract was weighed and dissolved in 10 $\mathrm{ml}$ of distilled water to get the stock solution of 100 $\mathrm{mg} / \mathrm{ml}$ at which a serial dilution was made using dilution factor of 1:10 to get stock concentrations of $10 \mathrm{mg} / \mathrm{ml}, 1$ $\mathrm{mg} / \mathrm{ml}$ and $0.1 \mathrm{mg} / \mathrm{ml}$. One gram each of acetylcholine and atropine was weighed and dissolved in $10 \mathrm{ml}$ of distilled water to get a stock concentration of $100 \mathrm{mg} / \mathrm{ml}$ at which serial dilutions was done using dilution factor of 
$1: 10$ to get stock solutions that was used for the in vitro experiments.

In vitro effect of ethanol leaf extract of Vernonia amygdalina on pregnant rat uterus

A white male California rabbit weighing $3.1 \mathrm{~kg}$ was starved for 24 hours prior to use, but it was allowed to take water. The animal was euthanized by a sharp blow on the base of the skull. A mid-line incision was made on the abdomen to expose the stomach and the intestine. A piece of the intestine $(2-3 \mathrm{~cm})$ was cut $(10 \mathrm{~cm}$ away from the stomach). The piece of the gut was freed from fat and other attachment before being preserved in aerated thyroid solution at $37^{\circ} \mathrm{C}$. The thyroid solution was aerated with $95 \%$ oxygen and $5 \%$ carbon dioxide. A white cotton thread in a needle was passed through both ends of the jejunum to form a loop and a knot. Care was taken not to close the lumen of the jejunum. The free end of the thread was attached to plasticine in the lever to record responses on the microdynometer. The other end of the gut was attached to the aerator pipe and anchored to the base of the tissue, both containing thyroid solution at $37^{\circ} \mathrm{C}$. The preparation was left to equilibrate for 30 minutes in a 50 $\mathrm{ml}$ capacity organ bath. The following drugs were tested on the rabbit jejunum; Acetylcholine $(0.1 \mathrm{mg} / \mathrm{ml}), V$. amygdalina extract $(100 \mathrm{mg} / \mathrm{ml})$ and Atropine $(0.1 \mathrm{mg} / \mathrm{ml})$. Graded volumes of the drugs were administered in the following order; $0.1,0.2,0.4,0.8$, and $1.6 \mathrm{ml}$. The organ bath was washed thrice after each dose before adding the next dose level. Zero point two milliliters $(0.2 \mathrm{ml})$ of $0.1 \mathrm{mg} / \mathrm{ml}$ atropine was administered concurrently with acetylcholine and the extract in same manner above. The responses recorded on the microdynometer were measured in millimeters against the respective final organ bath concentration.

\section{Phytochemical Analysis of the Leaf Extracts}

The preliminary phytochemical analysis of the leaf extract was conducted based on the standard method of Trease and Evans ${ }^{7}$ and Sofowora ${ }^{8}$.

Table 1: Qualitative phytochemistry of the ethanol extract of

\begin{tabular}{|c|c|}
\multicolumn{2}{|c}{ V. amygdalina leaf } \\
\hline Phytoconstituents & Results \\
\hline Tannins & + \\
\hline Flavonoids & - \\
\hline Phlabotannins & + \\
\hline Alkaloids & + \\
\hline Saponins & + \\
\hline Cardiac glycosides & + \\
\hline Anthraquinones & - \\
\hline Steroids & absent; $+=$ present
\end{tabular}

Table 2: Quantitative Phytochemistry of the leaf extract of

\begin{tabular}{|c|c|c|}
\hline \multicolumn{3}{|c|}{ V. amygdalina } \\
\hline Phytoconstituents & Methods & Results \\
\hline \multirow[t]{2}{*}{ Tannins } & Soluble & +++ \\
\hline & Condensed & +++ \\
\hline Phlabotannins & Ferric chloride test & ++ \\
\hline \multirow[t]{2}{*}{ Alkaloids } & Wagner's test & +++ \\
\hline & Dragendorff's test & +++ \\
\hline \multirow[t]{2}{*}{ Saponins } & Frothing test & +++ \\
\hline & Haemolysis test & +++ \\
\hline \multirow[t]{2}{*}{ Cardiac glycosides } & Salkowski test & ++ \\
\hline & Keller-Killiani test & ++ \\
\hline Anthraquinones & Borntrager's test & + \\
\hline
\end{tabular}

Table 3: Effects of graded doses of acetylcholine $(100 \mu \mathrm{g} / \mathrm{ml})$ on spontaneous contraction of isolated rabbit jejunum in a $50 \mathrm{ml}$ capacity organ bath

\begin{tabular}{|c|c|c|c|c|}
\hline $\begin{array}{c}\text { Vol. of Ach. administered } \\
(\mathrm{ml})\end{array}$ & $\begin{array}{c}\text { Final bath concentration } \\
(\mathrm{ng} / \mathrm{ml})\end{array}$ & $\begin{array}{c}\text { Log of final bath } \\
\text { concentration }\end{array}$ & $\begin{array}{c}\text { Response (mm) } \\
\text { Percentage Response } \\
(\%)\end{array}$ \\
\hline 0.1 & 200.00 & 2.30 & 16.00 & 53.33 \\
\hline 0.2 & 400.00 & 2.60 & 21.00 & 70.00 \\
\hline 0.4 & 800.00 & 2.90 & 24.00 & \\
\hline 0.8 & 1600.00 & 3.20 & 30.00 & \\
\hline 1.6 & 3600.00 & 3.51 & 29.00 & 100.00 \\
\hline
\end{tabular}

Table 4: Effects of graded doses of ethanol extract of $V$. amygdalina leaf $(100 \mathrm{mg} / \mathrm{ml})$ on spontaneous contraction of isolated rabbit jejunum

\begin{tabular}{|c|c|c|c|c|}
\hline $\begin{array}{c}\text { Vol. of extract administered } \\
(\mathrm{ml})\end{array}$ & $\begin{array}{c}\text { Final bath conc. } \\
(\mu \mathrm{g} / \mathrm{ml})\end{array}$ & $\begin{array}{c}\text { Log of final bath } \\
\text { concentration }\end{array}$ & $\begin{array}{c}\text { Response }(\mathrm{mm}) \\
\text { Percentage Response } \\
(\%)\end{array}$ \\
\hline 0.1 & 200.00 & 2.30 & 3.00 & 19.61 \\
\hline 0.2 & 400.00 & 2.60 & 100 & 45.20 \\
\hline 0.4 & 800.00 & 2.90 & 15.30 & 66.67 \\
\hline 0.8 & 1600.00 & 3.20 & 15.00 & 100.00 \\
\hline 1.6 & 3200.00 & 3.51 & & 98.03 \\
\hline
\end{tabular}

Table 5: Effects of interactive studies of acetylcholine and ethanol extract of $V$. amygdalina leaf with atropine

\begin{tabular}{|c|c|c|}
\hline & Final organ bath conc. & Response (mm) \\
\hline & $20 \mathrm{ng} / \mathrm{ml}$ & 0 \\
\hline Drugs & $40 \mathrm{ng} / \mathrm{ml}$ & 0 \\
\hline Ach + Atropine & $80 \mathrm{ng} / \mathrm{ml}$ & 5.2 \\
\hline & $160 \mathrm{ng} / \mathrm{ml}$ & 13.3 \\
\hline & $320 \mathrm{ng} / \mathrm{ml}$ & 0 \\
\hline & $200 \mu \mathrm{g} / \mathrm{ml}$ & 0 \\
\hline Extract + Atropine* & $400 \mu \mathrm{g} / \mathrm{ml}$ & 0 \\
\hline & $800 \mu \mathrm{gg} / \mathrm{ml}$ & 0 \\
\hline & $1600 \mu \mathrm{g} / \mathrm{ml}$ & 0 \\
\hline
\end{tabular}




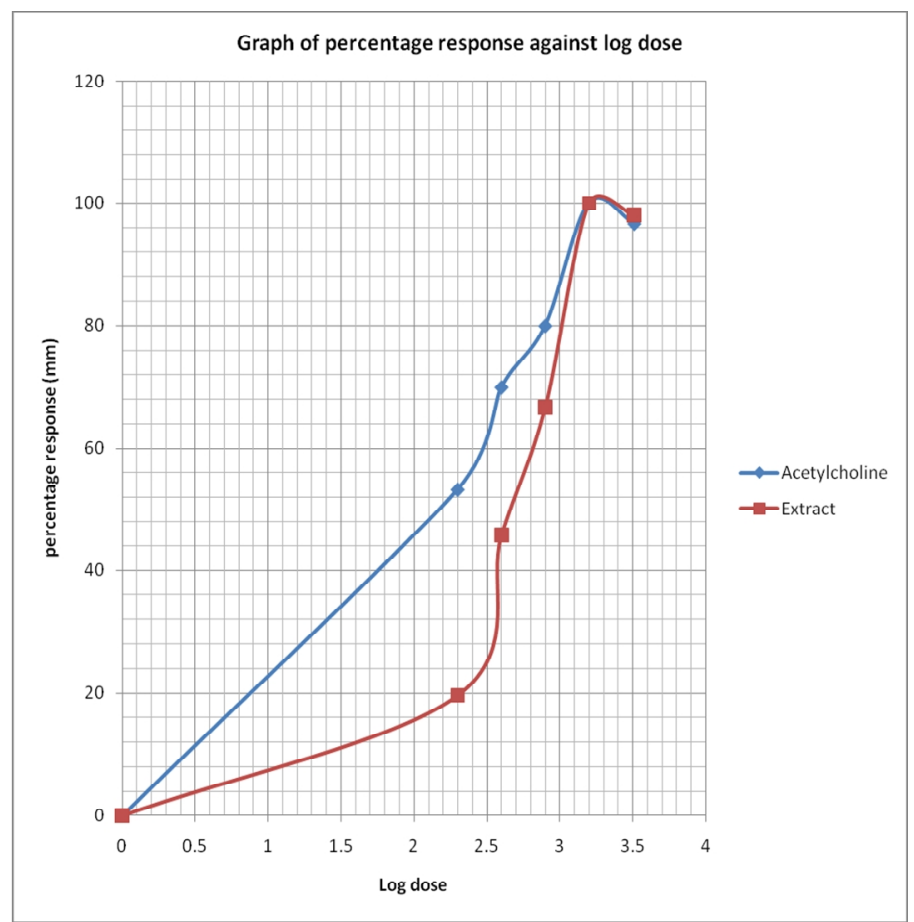

Figure 1: Effects of graded doses of acetylcholine and ethanol extract on rabbit jejunum

\section{RESULT AND DISCUSSION}

The result obtained from the phytochemistry showed that the ethanol extract of $V$. amygdalina contained tannins, phlabotannins, alkaloids, saponins, cardiac glycosides and anthraquinones. Flavonoids and steroids were not detected in the ethanol leaf extract (Table 1). Quantitatively, phytochemistry revealed the presence of tannins, alkaloids and saponins in high concentration, whereas phlabotannins and cardiac glycosides were seen in moderate concentration in the ethanol leaf extract of. However, anthraquinone was found in low concentration in the ethanol leaf extract (Table 2). The bitter taste usually associated with the plant could be due to the presence of non nutritional factors such as alkaloids, saponins, tannins, and glycosides ${ }^{9}$. These results contradict an earlier study done by Omenka et al ${ }^{10}$ which reported that ethanolic extract contains phlabotannins and anthraquinones. The variation in the environmental factors such as temperature and rainfall especially at the time of collection may be likely explanation for the difference. However, the result is in conformity with an earlier work by Ekam et al ${ }^{11}$ in which the ethanolic extract of Vernonia amygdalina contained all the secondary metabolites that were tested and were present in this study. The presence of alkaloid, saponin, and tannin in relative higher quantities agrees with the report of Ugwoke et al ${ }^{12}$ in which similar observation was made. The response elicited by the ethanol extract of Vernonia amygdalina on the rabbit jejunum which mimics that of acetylcholine may be attributable to one or more of these secondary metabolites detected. The results from the in vitro experiment on rabbit jejunum showed a depolarizing (contractile) response to the reference drug acetylcholine which was dose depended as it is shown in
Table 3. This was expected since acetylcholine increases the tone and amplitude of contraction of the stomach and intestine via muscarinic receptor ${ }^{13}$. The ethanol leaf extract showed similar effect as the reference drug and its response was also dose dependent. The increase in amplitude of the rabbit jejunum by the extract which is similar to that of acetylcholine may be viewed both as acting via muscarinic receptors ${ }^{14,}{ }^{15}$. The relative potencies of acetylcholine and the extract obtained on the same tissue can be describe by determining the effective concentrations that gives $50 \%$ biological response $\left(\mathrm{EC}_{50}\right)^{13}$. Figure I showed the $\mathrm{EC}_{50}$ for acetylcholine and extract extrapolated on the graph as $162 \mathrm{ng} / \mathrm{ml}$ and $501 \mu \mathrm{g} / \mathrm{ml}$ respectively. From these results it is evident that acetylcholine is relatively more potent than the extract. The wide margin in potency between the extract and acetylcholine might be because of the crude nature of the extract. Table 5 showed how atropine antagonizes the contractile activity of acetylcholine and the extract. This showed that atropine blocks the muscarinic receptor $\left(\mathrm{M}_{3}\right)$ on the jejunum which result in blocking the effect of acetylcholine and the extract. However, at high doses of acetylcholine $(160 \mathrm{ng} / \mathrm{ml}$ and $320 \mathrm{ng} / \mathrm{ml})$ the antagonistic effect of atropine was blocked. This agrees with the report of Rang et al ${ }^{16}$ in which atropine blocks the effect of acetylcholine through a reversible competitive antagonism at $\mathrm{M}_{3}$ receptors. When atropine was coadministered with the extract, it blocked the effect of the extract at all the dose levels used (Table 5). This showed that the extract may act via the same path as acetylcholine i.e. via the $\mathrm{M}_{3}$ receptors that are predominantly located on the gastrointestinal muscles. Acetylcholine stimulates $\mathrm{M}_{3}$ receptors through $\mathrm{Gq}$ protein. This is responsible for the stimulation of phopholipase $\mathrm{C}$ activity which catalyses the 
formation of two intracellular messengers; Inositol 1,3,5 triphosphate $\left(\mathrm{IP}_{3}\right)$ and Diacylglycerol (DAG). These lead to release of intracellular $\mathrm{Ca} 2+$ and the activation of phosphokinase $\mathrm{C}$ and finally the contraction of the jejunum $^{16}$.

\section{CONCLUSION}

The ethonol extract of the Vernonia amygdalina leaf contains secondary metabolites of pharmacological importance and may be responsible for a dose dependent contraction of the rabbit jejunum which was blocked by atropine. The blockade signifies that the extract might be acting via the $\mathrm{M}_{3}$ receptors on the intestine. These justify its ethno medical claim that the leaves are used as purgatives.

\section{ACKNOWLEDGEMENT}

Authors are sincerely thankful to staff of Department of Pharmacology and Toxicology, University of Maiduguri for their technical assistance and support.

\section{REFERENCES}

1. El- Kamali HH. Medicinal plants in East and Central Africa: challenges and constraints. Ethno Botanical Leaflets 2009; 13: 36469.

2. Roja G, Rao PS. Anticancer Compound from tissue culture of medicinal plants. Journal of Herbs, Spices and Medicinal Plants 2002; 7: 71-102. http://dx.doi.org/10.1300/J044v07n02 08

3. Iwu MM, Duncan AR, Okunji CO. New antimicrobials of plant origin in J. Janick (Ed). Prospective on new crops and new uses. ASHS Press, Alexandria VA. 1999; p 457-462.

4. Ifeoma IT, Chukwunonso EE, Obinna MN, Bryan CN. Effect of traditional processing techniques on the nutritional and phytochemical composition of African bread fruit (Treculia africana) seeds. J. Applied Sci and Environmental management 2010; 14(4): 169-173

5. Anoka AN, Bulus A, Amon GA, Dominic B, Silvia D, David RB. The analgesic and antiplasmodial activities and toxicology of $V$. amygdalina. Journal of Medicinal Food 2008; 11(3): 574-581. http://dx.doi.org/10.1089/jmf.2007.0511 PMid:18800909

6. Venton DL, Kim SO, Lee Breton GC. In: Wagner H., Fansworth WR., Economic and medicinal plants research. London: Academic Press, 1991; p 323-351.

7. Trease GE, Evans WC. Pharmacognosy. Baillaiere, Tindals, London. 1989; p 687-689.

8. Sofowora A. The state of medicinal plants research in Nigeria. University Press, Ibadan, Nigeria, 1978; p. 86.

9. Anon P, Opabode JI, Adegboye OC. Application of Biotechnology for the improvement of Nigerian indegenious leafy vegetables. Africa J. Biotechnology 2005; 4(3):138-142.

10. Omenka RO, Oyewole IO, Kayode AO. Phytochemical screening and antimicrobial testing of Vernonia amygdalina Del leaves on Salmonella typhi: Journal of Life and Physical Sciences 2004; 1(1): 56-59.

11. Ekam VS, Ebong PE, Umoh IB. Phytochemical screening of activity directed extract A of Vernonia amygdalina leaves. Global Journal of Pure and Applied Sciences 2010; 16(1): 66-69. http:// dx.doi.org/10.4314/gipas.v16i1.62824

12. Ugwoke CE, Nzekwe U, Ameh GI. Phytochemical constituent and ethnobotany of the leaf extract of bitter leaf (Vernonia amygdalina) Del. The Journal of Pharmaceutical and Allied Sciences 2010; 7(3): 88-91.

13. Lawrence JJ, Grinspan ZM, Statland JM, McBain CJ. Muscarinic receptor activation tunes mouse stratum oriens interneurons to amply spike reliability. J of Physiol (Lond) 2006; 571: 555-562. http://dx.doi.org/10.1113/jphysiol.2005.103218 PMid:16439425 PMCid:1805794

14. Lawrence DR, Bunnet PN. Clinical pharmacology. In Churchill Livingstone, $4^{\text {th }}$ Ed. 1996; p 1130-1132.

15. Ganong WF. Review of medical physiology. In Lange Medical Publication $18^{\text {th }}$ edition. 1998; p 111-113.

16. Rang HP, Dale MM, Ritta JM, Flower RJ. Rang and Dale's Pharmacology. $7^{\text {th }}$ Ed. 2007; p 43.

Cite this article as:

Wazis CH, Timothy SY, Zakama SG, Balla HJ, Maspalma ID. Phytochemical screening and purgative activity of Ethanolic extracts of Vernonia amygdalina Del. Leaf. Int. J. Res. Ayur. Pharm. 2013; 4(1): 46-49 